\title{
UJI KEMAMPUAN BAKTERI ( Pseudomonas aeruginosa) DALAM PROSES BIODEGRADASI PENCEMARAN LOGAM BERAT TIMBAL (Pb), DI PERAIRAN TIMUR KAMAL KABUPATEN BANGKALAN ABILITY TEST OF BACTERIA (Pseudomonas aeruginosa) IN BIODEGRADATION PROCESS OF LEAD HEAVY METAL (Pb) Pollution, IN EAST KAMAL WATERS, BANGKALAN REGENCY
}

\author{
Anestya Anggraeni dan Haryo Triajie ${ }^{2}$ \\ Program Studi Manajemen Sumberdaya Perairan, Universitas Trunojoyo Madura \\ ${ }^{*}$ Corrersponden author email: haryotriajie@trunojoyo.ac.id \\ Submitted: 08 September 2021 / Revised: 27 September 2021 / Accepted: 28 September 2021 \\ http://doi.org/10.21107/juvenil.v2i3.11754

\begin{abstract}
ABSTRAK
Perairan selat Madura merupakan perairan yang rentan tercemar bahan-bahan limbah berbahaya, salah satu sumber pencemar adalah logam berat. Adanya logam berat di perairan berbahaya baik secara langsung terhadap kehidupan organisme, maupun efeknya secara tidak langsung terhadap kesehatan manusia. Hal ini berkaitan dengan sifat-sifat logam berat yaitu sulit terurai, sehingga mudah terakumulasi dalam lingkungan perairan dan keberadaannya secara alami sulit terurai, untuk mengatasi pencemaran logam timbal $(\mathrm{Pb})$ adalah dengan memanfaatkan bakteri Pseudomonas aeruginosa. Tujuan dari penelitian ini yaitu untuk mengetahui aktifitas bakteri Pseudomonas aeruginosa dalam menurunkan logam timbal (Pb) pada perairan Timur Kamal. Penelitian ini dilakukan pada bulan November 2020-Februari 2021. Metode yang digunakan yaitu uji degradasi dengan analisa kandungan logam timbal $(\mathrm{Pb})$, pengukuran optikal density dan uji degradasi menggunakan bakteri Pseudomonas aeruginosa. Hasil penelitian menunjukkan bahwa Aktifitas bakteri Pseudomonas aeruginosa dalam menurunkan kandungan logam timbal $(\mathrm{Pb}$ ) dipelabuhan Timur Kamal yaitu sampel 1.1 penurunan sebesar 92,3\%, sampel 1.2 penurunan sebesar 92,8\%, sampel 2.1 penurunan sebesar 95,5\%, sampel 2.2 penurunan sebesar 97,3\%, sampel 3.1 penurunan sebesar 91,3\% dan untuk sampel 3.2 penurunan sebesar 87,5\%. Waktu inkubasi optimum untuk menurunkan kadar logam timbal $(\mathrm{Pb})$ yaitu pada hari ke 4 waktu inkubasi.
\end{abstract}

Kata Kunci: Logam Timbal, Bakteri Pseudomonas aeruginosa, uji degradasi

\section{ABSTRACT}

The waters of the Madura Strait are waters that are prone to being contaminated by hazardous waste materials. One of the sources of pollution is heavy metals. The presence of heavy metals in waters is dangerous, either directly to the life of organisms, or its effect on human health. This is related to the properties of heavy metals, which are difficult to decompose, so that they are easily accumulated in the aquatic environment and naturally difficult to decompose. To overcome lead metal $(\mathrm{Pb})$ contamination is to use the Pseudomonas aeruginosa bacteria. The purpose of this study was to determine the activity of the Pseudomonas aeruginosa bacteria in lowering lead metal (Pb) in the waters of East Kamal. This research was conducted in November 2020-February 2021. The method used was the degradation test with analysis of lead $(\mathrm{Pb})$ metal content, optical density measurement and degradation test using Pseudomonas aeruginosa bacteria. The results showed that the activity of the Pseudomonas aeruginosa bacteria in reducing the metal content of lead (Pb) in East Kamal port was sample 1.1 decreased by $92.3 \%$, sample 1.2 decreased by $92.8 \%$, sample 2.1 decreased by $95.5 \%$, sample 2.2 decreased of $97.3 \%$, for sample 3.1 the decrease was $91.3 \%$ and for sample 3.2 the decrease was $87.5 \%$. The optimum incubation time to reduce levels of lead $(\mathrm{Pb})$ is on the 4th day of incubation .

Keywords: Lead Metal, Pseudomonas aeruginosa Bacteria, degradation tes 
Juvenil, 2(3), 176-185, (2021)

\section{PENDAHULUAN}

Indonesia memiliki wilayah sebagian besar laut, tidak bisa dipungkiri kekayaan Indonesia sangatlah besar. Luas laut Indonesia yang mencapai 5,8 juta $\mathrm{km}^{2}$, terdiri dari 0,3 juta $\mathrm{km}^{2}$ perairan teritoral, 2,8 juta $\mathrm{km}^{2}$ perairan pedalaman dan kepulauan. Pulau Madura merupakan pulau yang terletak di sebelah timur laut Jawa Timur. Pulau Madura besarnya kurang lebih $5.250 \mathrm{~km}^{2}$ dengan penduduk sekitas 4 juta jiwa, merupakan salah satu pulau yang memiliki kekayaan biota yang tinggi. Perairan selat Madura merupakan perairan yang rentan tercemar bahan-bahan limbah berbahaya, sumber bahan pencemar berasal dari berbagai kegiatan industri rumahan. Jumlah industri di Jawa Timur yang menyumbang bahan pencemar ke Selat Madura melalui beberapa muara sungai yaitu 483 industri (Khoiroh, 2014).

Pencemaran air adalah masuknya atau dimasukkannya makhluk hidup, zat, energi dan atau komponen lain ke dalam air oleh kegiatan manusia, sehingga kualitas air turun sampai ke tingkat tertentu yang menyebabkan air tidak dapat berfungsi sesuai dengan peruntukkannya. Salah satu sumber pencemar adalah logam berat. Adanya logam berat di perairan berbahaya baik secara langsung terhadap kehidupan organisme, maupun efeknya secara tidak langsung terhadap kesehatan manusia. Hal ini berkaitan dengan sifat-sifat logam berat yaitu sulit terurai, sehingga mudah terakumulasi dalam lingkungan perairan dan keberadaannya secara alami sulit terurai. Berdasarkan sudut pandang toksikologi, logam berat ini dapat dibagi menjadi dua jenis. Jenis pertama adalah logam berat esensial di mana keberadaannya dalam jumlah tertentu sangat dibutuhkan oleh organisme hidup, namun dalam jumlah yang berlebihan dapat menimbulkan efek racun, sedangkan jenis kedua adalah logam berat non esensial atau beracun, dimana keberadaannya dalam tubuh masih belum diketahui manfaatnya atau bahkan dapat bersifat racun seperti timbal $(\mathrm{Pb})$ (Mohiuddin, 2011)

Salah satu metode untuk mengatasi pencemaran logam timbal $(\mathrm{Pb})$ adalah dengan memanfaatkan bakteri. Seperti penelitian yang dilakukan oleh (Panuntun \& Yulianto, 2012) yang menemukan 3 isolat bakteri yaitu genus Entrococcus, Lactobacillus dan Pseudomonas dengan kemampuan toleran timbal hingga kadar $0,3 \mathrm{ppm}$. Beberapa jenis bakteri dilaporkan memiliki aktifitas penyerapan terhadap logam $\mathrm{Pb}$. Bakteri-bakteri tersebut berasal dari beberapa genus yang berbeda. Beberapa bakteri yang sudah dilaporkan mempunyai kemampuan untuk menyerap logam $\mathrm{Pb}$ yaitu Bacillus sp, Corynebacterium glutamicum, Enterobacter sp, pseudomonas putida, Streptomyces rimosus, Streptoverticillium cinnamoneum, dan Symphortcarpus albus. Mikroorganisme mampu bertahan dalam lingkungan dengan kadar logam berat yang tinggi bergantung pada kemampuan detoksifikasi mikroorganisme tersebut. Bakteri memiliki mekanisme yang berbeda-beda dalam toleransi dan dalam proses bioremediasi logam berat dari lingkungan. Beberapa mekanisme yang sudah diketahui digunakan oleh bakteri dalam mentoleransi kadar logam berat. Pseudomonas aeruginosa adalah bakteri gram negatif aerob obligat, berkapsul, mempunyai flagella polar seingga bakteri ini bersifat motil, berukuran sekitar 0,5-1,0 um. Pseudomonas secara umum tidak memiliki enzim hidrolitik yang penting dalam mendegradasi polimer menjadi monomer namun bakteri ini memiliki system inducible operon yang mampu menghasilkan enzim tertentu dalam proses metabolisme sumber karbon yang tidak biasa digunakan oleh karena itu bakteri ini memiliki peran penting dalam proses biodegradasi (Sriningsih et al., 2015).

\section{MATERI DAN METODE}

Penelitian ini dilaksanakan pada bulan November 2020- Februari 2021 yang meliputi pengambilan sampel air laut. Metode yang digunakan adalah menggunakan metode Atomic Absorption Spectrometry (AAS) dengan dua titik pengambilan sampel. Analisa dilaksanakan di Laaboratorium Manajemen Sumberdaya Perairan.

Metode pengambilan data menggunakan metode purposive sampling yang merujuk pada kondisi lingkungan diperairan Timur Kamal. Secara geografis letak lokasi stasiun 1 dan 2 ialah S $07.10452^{\circ}$ E $112.43906^{\circ}$ dan S $07.10553^{\circ}$ E $112.435071^{\circ}$. Pengambilan sampel pada perairan sebagai bahan uji pendegradasi tingkat pencemar $\mathrm{Pb}$. Pengambilan sampel air di lakukan pada masing masing stasiun. Sampel air dilakukan pengambilan pada setiap bulannya selama 3 bulan. Kemudian sampel air disimpan didalam cool box dan dibawa ke laboratorium untuk dianalisa keberadaan $\mathrm{Pb}$. kurva standar logam timbal $\mathrm{Pb}$ yang digunakan sebagai standar analisa logam. 

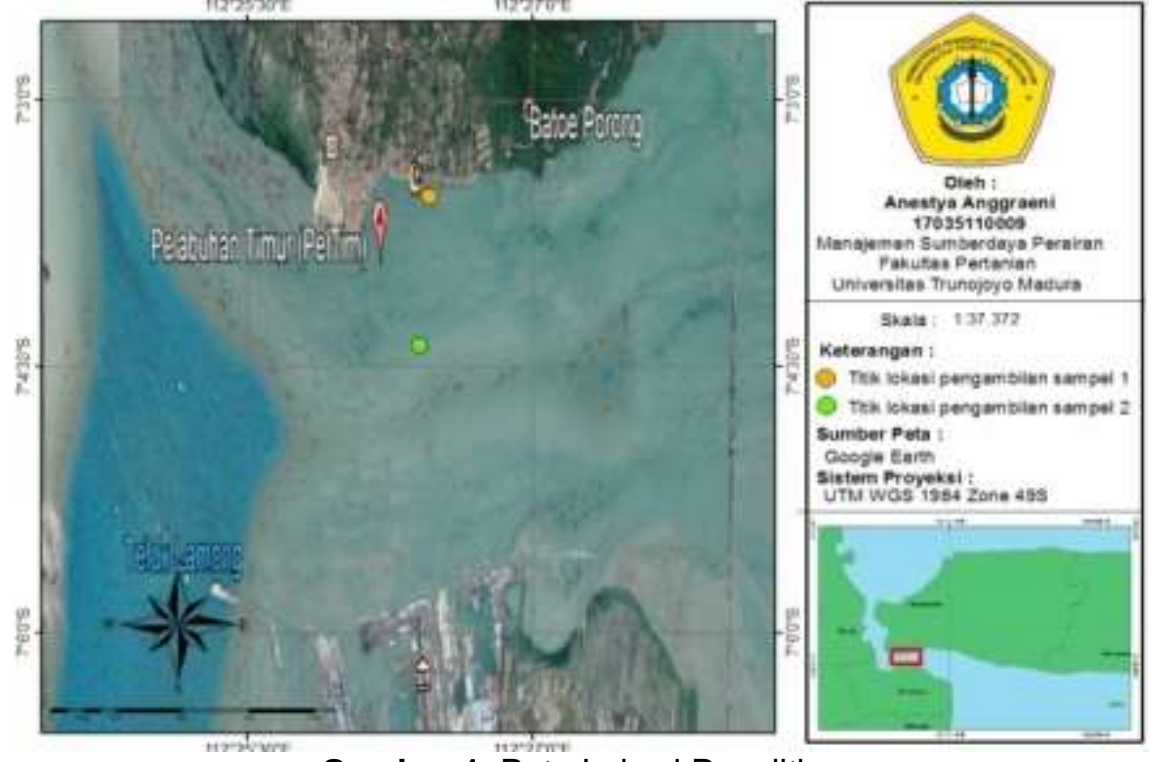

Gambar 1. Peta Lokasi Penelitian

\section{Sterilisasi Alat dan Bahan}

Alat yang digunakan penelitian baik dilapang maupun laboratorium disterilkan terlebih dahulu. Sterilisasi yang digunakan yaitu oven, sterilisasi dengan metode ini digunakan untuk benda-benda dari kaca atau gelas, seperti pipet ukur, Erlenmeyer dan tabung reaksi, tidak boleh bahan yang terbuat dari karet atau plastic. Oven Suhu $180^{\circ} \mathrm{C}$ selama 30 menit. Alat-alat tersebut terlebih dahulu dibungkus menggunakan kertas sebelum dilakukan sterilisasi. Sterilisasi dengan pemanasan yaitu bunsen yang digunakan untuk sterilisasi berupa jarum ose dengan memanaskan peralatan tersebut diatas nyala api bunsen sampai berpijar. Autoklaf merupakan sterilisasi panas basah, sterilisasi menggunakan autoklaf terlebih dahulu peralatan yang akan disterilisasi di bersihkan dengan air, dibersihkan dengan tissue, sedangkan sterilisasi bahan yaitu berupa media NA dan media NB yang sebelumnya ujung botol ditutup menggunakan kapas, alumunium foil dan cling wrap. Sterilisasi menggunakan autoklaf membutuhkan waktu 15 -20 menit dengan suhu $121^{\circ} \mathrm{C}$ (Andriani et al., 2016)

\section{Pembuatan Larutan atau Kurva Standar Logam (Pb)}

kurva standar logam timbal $\mathrm{Pb}$ yang digunakan sebagai standar analisa logam. Kurva standar logam timbal $(\mathrm{Pb})$ dibuat dari larutan standar $\mathrm{Pb}$ 1000ppm. Iarutan kemudian dibuat stok $10 \mathrm{ppm}$ sebanyak 250 $\mathrm{ml}$. Pembuatan Larutan stok melalui rumus pengenceran (Mulyono, 2006).

$M_{1} \times V_{1}=M_{2} \times V_{2}$
Keterangan $=$

$$
\begin{aligned}
& V_{1}=\text { Volume larutan standar yang } \\
& \text { diencerkan } \\
& V_{2}=\text { Volume larutan pengenceran } \\
& M_{1}=\text { Konsentrasi larutan yang } \\
& \text { diengenceran } \\
& M_{2}=\text { Konsentrasi larutan pengenceran }
\end{aligned}
$$

\section{Pengukuran Kadar Logam Timbal (Pb)}

Pengukuran kadar logam berat timbal (Pb) dilakukan menggunakan AAS.

\section{Pembuatan Media Padat}

Pembuatan media padat yaitu menggunakan media Nutrien Agar (NA). Menimbang sebanyak 2,3 NA dilarutkan ke dalam $100 \mathrm{~mL}$ aquades dan di aduk sambil dipanaskan di hotplate sampai panas sempurna, Selanjutnya disterilisasi media padat pada autoklaf pada suhu $121^{\circ} \mathrm{C}$ selama 15 menit (Caesar et al., 2014).

\section{Peremajaan dan Pembuatan Starter Bakteri}

Peremajaan isolat bakteri Pseudomonas aeruginosa dilakukan menggunakan media padat miring yaitu Nutrien Agar (NA). Di ambil 1 ose bakteri dari stok atau koleksi, kemudian di streak menggunakan media NA miring dan inkubasi pada suhu $37^{\circ} \mathrm{C}$ selama 24 jam. Peremajaan bakteri Pseudomonas aeruginosa bertujuan untuk memperoleh stok bakteri yang ditumbuhkan dari media satu ke media lainnya. Isolat murni bakteri yang diremajakan diperoleh dari Balai besar lingkungan kesehatan Surabaya. Bakteri diremajakan dengan cara metode gores pada tabung reaksi yang sebelumnya telah dituangkan media NA (Nutrient agar). 


\section{Pembuatan Media Cair}

Pembuatan Media Cair yaitu menggunakan media NB (Nutrien Broth) dengan menambahkan 0,8 gram NB dan dilarutkan ke dalam $100 \mathrm{~mL}$ aquades diaduk sambil dipanaskan sampai larut sempurna, selanjutnya disterilisasi didalam autoklaf pada suhu $121^{\circ} \mathrm{C}$ selama 15 menit ( Caesar et al., 2014).

\section{Pembuatan Inokulum Bakteri}

Inokulasi mikroorganisme adalah suatu pekerjaan untuk memindahkan bakteri dari media lama ke dalam media yang baru. Pembuatan Inokulum bakteri dimulai dari memipet $15 \mathrm{ml}$ NB yang kemudian dimasukkan kedalam botol kultur, selanjutnya mengambil 1 ose isolat bakteri Pseudomonas aeruginosa dimasukkan ke dalam botol kultur dan ditutup menggunakan kapas, alumunium foil dan cling wrap. Diamkan dalam suhu ruang selama $1 \times 24$ jam.

Inokulasi mikroorganisme adalah suatu pekerjaan untuk memindahkan bakteri dari media lama ke dalam media yang baru. Mikroorganisme yang digunakan sebagai bahan inokulum adalah bakteri dengan spesies Pseudomonas aeruginosa. Inokulasi dilakukan pada media cair (Nutrient Broth) dengan cara mengambil 1 ose bakteri Pseudomonas aeruginosa dari kultur stok yang di masukkan dalam media cair sebanyak $15 \mathrm{ml}$. Media yang telah berisi bakteri diinkubasi pada suhu ruang selama 24 jam, setelah 24 jam inokulum pada media yang awalnya bening dan setelah penambahan bakteri terdapat lapisan yang berwarna putih pucat yang berada dipermukaan media NB hal tersebut dikarenakan adanya pertumbuhan bakteri. Setelah itu, akan terlihat penambahan dari koloni sel bakteri Pseudomonas aeruginosa yang dapat dilihat dengan mata telanjang. Setelah di inkubasi selama 24 jam, inokulum dimasukkan kedalam botol kultur sebanyak 36 botol dengan masing-masing botol ditambahkan inokulum sebanyak $1 \%(0,3$ $\mathrm{ml}$ ). Penambahan inokulum sebanyak $0,5 \mathrm{ml}$ berdasarkan rumus sebagai berikut:

$1 \%=1 / 100 \times$ (Jumlah Media yang digunakan)

Berdasarkan rumus diatas, dapat diketahui penambahan inokulum sebanyak $1 \%$ didapatkan dari jumlah media yang digunakan yaitu $30 \mathrm{ml}$ media NB dalam proses degradasi dibagi dengan 100 yang hasilnya adalah 0,3

\section{Perhitungan Optical Density (OD)}

Penghitungan nilai Optical density (OD) dilakukan dengan mengukur nilai absorbansi masing-masing sampel yang telah diambil. Hasil pengukuran nilai OD (optical density) dengan menggunakan spektrofotometer $(\lambda$ $610 \mathrm{~nm}$ ) menunjukkan nilai absorbansi yang berbeda dari setiap sampel yang diamati (Lizayana et al., 2016). Hasil perhitungan Optical Density dianalisis menggunakan software Ms. Excel dan SPSS.

\section{Uji degradasi logam timbal (Pb) oleh bakteri Pseudomonas aeruginosa}

Menimbang media NB sebanyak 1,5 gram dan melarutkannya dengan $150 \mathrm{ml}$ aquades steril. Menambahkan timbal asetat $\left(\mathrm{Pb}\left(\mathrm{CH}_{3} \mathrm{COO}\right)_{2}\right)$ hingga konsentrasi $1 \mathrm{ppm}$. memasukkan isolat bakteri sebanyak 2 ose ke dalam media tersebut kemudian dishaker dan diinkubasi selama 72 jam. Dilakukan pengambilan sampel setiap 24 jam. Selanjutnya sampel disentrifus (12000 rpm, 5 menit) dan di ambil supernatannya (Chaterjee et al., 2012). $5 \mathrm{~mL}$ supernatan kemudian didestruksi dengan 0,5 $\mathrm{ml}$ asam nitrat $\left(\mathrm{HNO}_{3}\right)$ pekat sambil dipanaskan dengan jernih, setelah itu sambil disaring menggunakan labu takar $50 \mathrm{~mL}$, ditambahkan standar timbal $(\mathrm{Pb})$ hingga konsentrasi $1 \mathrm{ppm}$, dan di impitkan dengan aquades steril. Sebelum proses analisis terlebih dahulu dibuat larutan standar timbal $\mathrm{Pb}$ ) dengan membuat larutan baku $100 \mathrm{ppm}$ dari larutan induk 1000 ppm, kemudian diencerkan menjadi $10 \mathrm{ppm}$ dan dibuat deret standar $1 \mathrm{ppm}, 1,2 \mathrm{ppm}, 1,4 \mathrm{ppm}, 1,6 \mathrm{ppm}$, $1,8 \mathrm{ppm}$, dan $2 \mathrm{ppm}$. sampel yang telah selesai di preparasi beserta standar tersebut dianalisis menggunakan instrumen spektrofotometer serapan atom (AAS) (Basha \& Rajaganesh, 2014).

\section{Perhitungan \% penurunan kadar logam}

Penentuan presentase logam berat $\mathrm{Pb}$ dengan menghitung daya reduksi (DR) sesuai persamaan (Husain dan Irna, 2005) :

$D R=\frac{C(a)-C(b)}{C(a)} \times 100 \%$

Keterangan :

$$
\begin{aligned}
& \mathrm{C}(\mathrm{a})=\text { Konsentrasi awal } \mathrm{Pb}(\mathrm{ppm}) \\
& \mathrm{C}(\mathrm{b})=\text { Konsentrasi akhir } \mathrm{Pb}(\mathrm{ppm}) \\
& \mathrm{DR}=\text { Daya reduksi }
\end{aligned}
$$


Anggraeni dan Triajie, Uji Kemampuan Bakteri (Pseudomonas aeruginosa)

\section{HASIL DAN PEMBAHASAN \\ Parameter Kualitas Air}

Hasil pengamatan kualitas air dapat dilihat pada Tabel 1. berdasarkan pengukuran salinitas, salinitas tertinggi berada pada stasiun 1 dan stasiun 2 yaitu dengan nilai 35 ppt terjadi pada bulan November. Nilai salinitas sesuai baku mutu air laut menurut KMNLP no 51 tahun 2004 sebesar $33-34$ $\%$. Salinitas stasiun 1 dan 2 di bulan November melebihi baku mutu. Menurut Nova (2012) laut yang dipengaruhi arus panas maka nilai salinitasnya tinggi, Semakin banyak terjadi penguapan, maka udara di sekitar menjadi lembab. Maka semakin tinggi pula salinitas air laut. Berdasarkan pengukuran suhu diperairan pelabuhan timur kamal, suhu pada stasiun 1 berkisar antara $30-32^{\circ} \mathrm{C}$ dan pada stasiun 2 suhu berkisar antara $25-27^{\circ} \mathrm{C}$. Mukhtasor (2007) mengemukakan jika kadar $\mathrm{Pb}$ pada air dipengaruhi oleh suhu, pada suhu yang tinggi senyawa logam berat akan larut dalam air. Suhu tertinggi terdapat pada stasiun

Tabel 1. Parameter Kualitas Air
1 dengan waktu pengamatan 02.00-02.30 sedangkan suhu terendah terdapat pada stasiun 2 dengan waktu pengamatan 02.3003.00. Happy et al., (2012) menerangkan bahwa intensitas tertinggi dari panas matahari yang menyebabkan suhu dipermukaan meningkat. Nilai DO tertinggi terjadi pada bulan November sedangkan DO rendah terletak pada bulan Desember dan Januari, DO rendah diakibatkan hujan yang terus menerus selama 2 hari sebelum pengambilan sampel. Namun, pada bulan November nilai DO masih di bawah ambang batas baku mutu KMNLP No.51 tahun 2004 yang diperuntukkan untuk biota laut berkisar antara $>5$. Jika $\mathrm{pH}$ rendah kelarutan logam berat akan lebih tinggi sehingga akan menyebabkan toksisitas logam berat semakin besar. (Pescod, 1973). Nilai pH pada stasiun 1 yaitu berkisar antara 6,96- 7,90 dan pada stasiun 2 berkisar 5,3-6,75. Nilai kedua stasiun masih normal dari baku mutu yang ditentukan sesuai dengan KMNLP No 51 tahun 2004 yaitu $7-8,5$.

\begin{tabular}{cccccccc}
\hline & \multicolumn{2}{c}{ November } & \multicolumn{2}{c}{ Desember } & \multicolumn{2}{c}{ Januari } & $\begin{array}{c}\text { KMNLH No 51 } \\
\text { Tahun 2004 }\end{array}$ \\
\hline $\begin{array}{c}\text { Parameter } \\
\text { Kualitas Air }\end{array}$ & $\begin{array}{c}\text { Stasiun } \\
1\end{array}$ & $\begin{array}{c}\text { Stasiun } \\
2\end{array}$ & $\begin{array}{c}\text { Stasiun } \\
1\end{array}$ & $\begin{array}{c}\text { Stasiun } \\
2\end{array}$ & $\begin{array}{c}\text { Stasiun } \\
1\end{array}$ & $\begin{array}{c}\text { Stasiun } \\
2\end{array}$ & \\
\hline Salinitas (ppt) & 35 & 35 & 30 & 30 & 30 & 31 & $33-34$ \\
Suhu ( $\left.{ }^{\circ} \mathrm{C}\right)$ & 32 & 25 & 31,7 & 25 & 30 & 27 & $28-32$ \\
DO (ppm) & 8,77 & 9,37 & 0,3 & 0,4 & 0,5 & 0,4 & $>5$ \\
pH & 7,86 & 6,08 & 6,96 & 6,75 & 5,90 & 5,34 & $7-8,5$ \\
\hline
\end{tabular}

Tabel 2. Data Absorbansi Larutan Standart Pb

\begin{tabular}{ccc}
\hline No. & Konsentrasi $(\mathbf{p p m})$ & Absorbansi \\
\hline 1. & 5 & 0,0003 \\
2. & 10 & 0,0005 \\
3. & 15 & 0,0011 \\
4. & 30 & 0,0018 \\
\hline
\end{tabular}

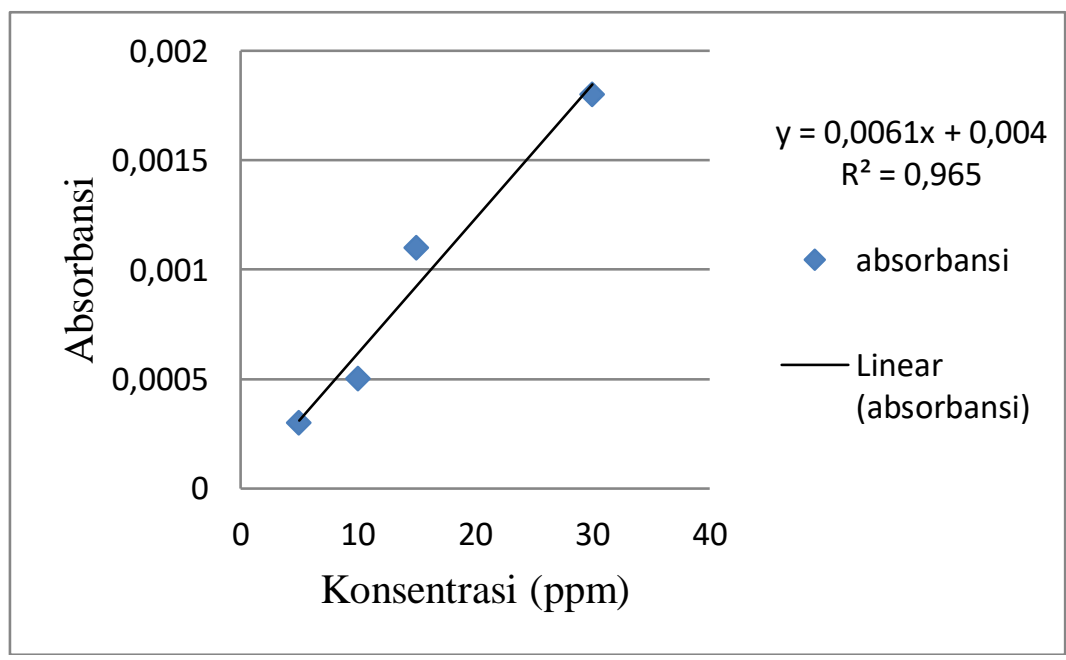

Gambar 1. Grafik Kurva Standart Pb 


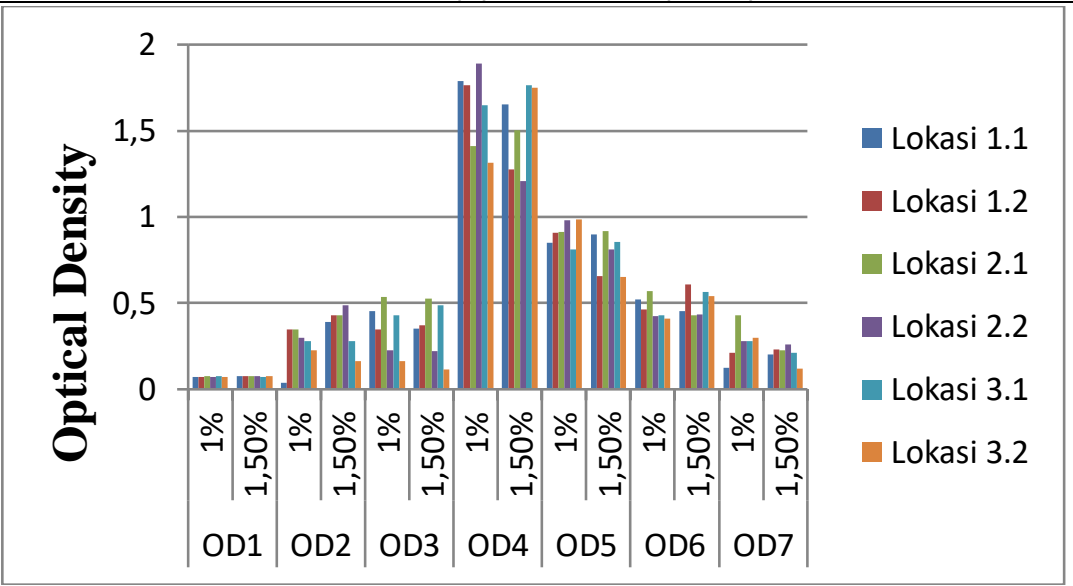

Gambar 2. Grafik Optikal Density (OD)

Tabel 3. Uji Anova

\begin{tabular}{lcrlrlccccc}
\hline $\begin{array}{l}\text { Waktu pengamatan } \\
\text { (Bulan) }\end{array}$ & \multicolumn{1}{l}{ OD Hari ke- } & $\mathbf{1}$ & $\mathbf{2}$ & & $\mathbf{3}$ & $\mathbf{4}$ & $\mathbf{5}$ & $\mathbf{6}$ & $\mathbf{7}$ & \\
\hline B1 & 0,071 & 0,267 & $\mathrm{~b}$ & 0,331 & $\mathrm{~B}$ & 1,428 & 0,734 & 0,404 & 0,143 & $\mathrm{~A}$ \\
B2 & 0,069 & 0,273 & $\mathrm{~b}$ & 0,258 & $\mathrm{Ab}$ & 1,183 & 0,796 & 0,411 & 0,244 & $\mathrm{~B}$ \\
B3 & 0,072 & 0,145 & $\mathrm{a}$ & 0,176 & $\mathrm{~A}$ & 1,196 & 0,751 & 0,433 & 0,175 & $\mathrm{Ab}$ \\
\hline Standart Deviasi & 0,001 & 0,072 & & 0,077 & & 0,138 & 0,032 & 0,016 & 0,051 & \\
\hline
\end{tabular}

Tabel 4. Perbandingan Kandungan Timbal Sebelum dan Setelah Penambahan Isolat Bakteri Pseudomonas aeruginosa

\begin{tabular}{lllll}
\hline No. & $\begin{array}{l}\text { Nama } \\
\text { Sampel } \\
\text { Lokasi }\end{array}$ & $\begin{array}{l}\text { Konsentrasi } \\
\text { Sebelum Degradasi } \\
(\mathrm{ppm})\end{array}$ & $\begin{array}{l}\text { Konsentrasi } \\
\text { Sesudah Degradasi } \\
(\mathrm{ppm})\end{array}$ & $\begin{array}{l}\text { Berdasarkan Keputusan Menteri } \\
\text { Negara Lingkungan Hidup No. } \\
179 \text { Tahun 2004 }\end{array}$ \\
\hline 1. & 1.1 & 0,131 & 0,010 & \\
2. & 1.2 & 0,084 & 0,006 & 0,008 \\
3. & 2.1 & 0,174 & 0,007 & \\
4. & 2.2 & 0,115 & 0,003 & \\
5. & 3.1 & 0,186 & 0,016 & \\
6. & 3.2 & 0,096 & 0,012 & \\
\hline
\end{tabular}

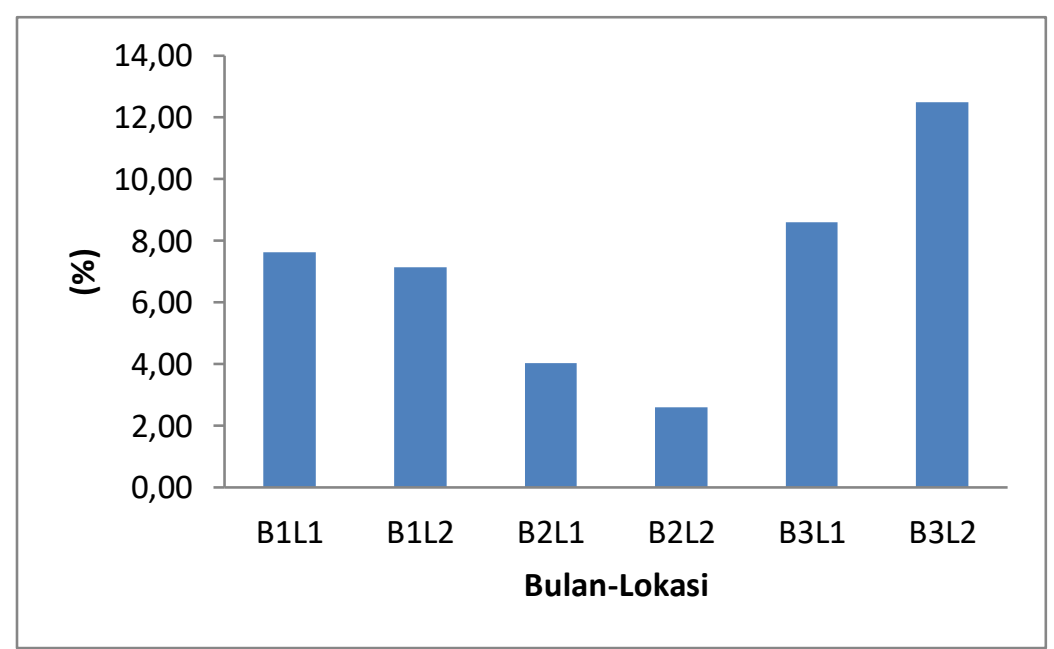

Gambar 3. Rasio Setiap Bulan di Kedua Lokasi

\section{Larutan Standart Logam Berat Timbal $(\mathbf{P b})$}

Uji linieritas penentuan regresi dari standar kurva, diperoleh koefisien korelasi dan diketahui kondisi alat spektrofotometer yang digunakan sudah mewakili semua sampel.
Hasil dari kurva standar dapat di lihat pada Gambar 1. diperoleh nilai korelasi $R$ sebesar 0,965 . Nilai $R$ dari hasil analisis larutan standar dalam penelitian ini menunjukkan hasil yang baik karena mendekati 1. Hal ini memperlihatkan bahwa terdapat hubungan 
Anggraeni dan Triajie, Uji Kemampuan Bakteri (Pseudomonas aeruginosa)

yang proporsional antara serapan (respon analitik) dengan konsentrasi yang diukur. Menurut Kartikasari (2016) menyatakan bahwa nilai koefisien korelasi $R>96$ maka dapat dikatakan baik. Oleh karena itu nilai koefisien korelasi kurva standart yang dibuat dapat digunakan untuk mengukur kadar timbal dalam sampel dengan spektrofotometer serapan atom (SSA).

\section{Pengukuran Optical Density (OD)}

Grafik pertumbuhan bakteri Pseudomonas aeruginosa yang dapat dilihat pada Gambar 2. bertujuan untuk mengetahui fase pertumbuhan bakteri pada media berisi sampel yang mengandung limbah timbal. Berdasarkan pengukuran kepadatan bakteri Pseudomonas aeruginosa yaitu berada pada fase logaritmik dengan waktu inkubasi 4 hari, dimana pada fase tersebut merupakan waktu inkubasi optimum yang dibutuhkan oleh bakteri Pseudomonas aeruginosa untuk mengikat logam timbal yaitu pada hari ke-4 inkubasi yang ditandai dengan adanya penurunan konsentrasi timbal yang ada dalam limbah cair yang digunakan dan bakteri ini juga dapat menyusun bahan anorganik menjadi senyawa organik yang lebih kompleks.

Pengukuran OD (optical density) pada hari ke-4 Nilai tertinggi dari sampel lokasi 1.1, konsentrasi $1 \%$ sebesar 1,7877 terjadi pada ulangan ke-3, sedangkan nilai tertinggi pada konsentrasi 1,5\% sebesar 1,6541 terjadi pada ulangan ke-2. Nilai OD tertinggi pada lokasi 1.2 dengan konsentrasi $1 \%$ sebesar 1,7651, sedangkan nilai tertinggi pada konsentrasi $1,5 \%$ sebesar 1,2748 . Nilai OD tertinggi pada lokasi 2.1 dengan konsentrasi 1\% sebesar 1,4089, sedangkan nilai tertinggi pada konsentrasi $1,5 \%$ sebesar 1,5021 . Nilai OD tertinggi pada lokasi 2.2 dengan konsentrasi $1 \%$ sebesar 1,8911 , sedangkan nilai tertinggi pada konsentrasi $1,5 \%$ sebesar 1,2101. Nilai OD tertinggi pada lokasi 3.1 dengan konsentrasi $1 \%$ sebesar 1,6501, sedangkan nilai tertinggi pada konsentrasi $1,5 \%$ sebesar 1,7632. Nilai OD tertinggi pada lokasi 3.2 dengan konsentrasi $1 \%$ sebesar 1,3165, sedangkan nilai tertinggi pada konsentrasi $1,5 \%$ sebesar 1,7521 . Hari ke- empat bakteri Pseudomonas aeruginosa sudah berada pada fase logaritmik ditandai dengan nilai OD atau kepadatan bakteri yang pertumbuhannya naik secara cepat. Menurut Reiny (2012) fase logaritmik menggambarkan sel membelah diri dengan ditandai laju yang konstan, masa menjadi dua kali lipat dengan laju sama, aktifitas metabolisme konstan, serta keadaan pertumbuhan seimbang.

\section{Uji Anova}

Penelitian ini menggunakan rancangan acak lengkap (RAL) dengan 2 (dua) faktor yaitu faktor waktu (bulan) dan faktor Dosis dengan 3 ulangan. Pengolahan Data OD (optical density) menggunakan uji anova yang terdapat pada pengambilan sampel bulan pertama (B1), bulan ke-dua (B2) dan bulan ke-tiga (B3). OD dari uji anova pada hari ke-2, hari ke-3 dan hari ke 7 berpengaruh nyata dan pada $\mathrm{B} 1$ hari ke-2, ke-3 dan ke-4 berbeda nyata dengan perlakuan pada B3. Jumlah OD tertinggi pada Hari ke-2 sebesar 0,267 pada B1 dan pada B2 sebesar 0,273 sedangkan terendah pada B3 sebesar 0,145. OD hari ke-3 tertinggi pada B1 sebesar 0,331 sedangkan terendah pada B3 sebesar 0,176 . OD pada hari ke-7 tertinggi berada pada B2 sebesar 0,244 dan terendah pada B1 yaitu sebesar 0,413 . dan pada hari ke-1, hari ke-4, hari ke-5, dan hari ke-6 tidak berbeda nyata.

\section{Hasil Uji Degradasi Logam Timbal Sebelum dan Sesudah Penambahan Bakteri Pseudomonas aeruginosa}

Hasil pengukuran dapat dilihat pada Tabel 4. diketahui bahwa kadar logam timbal $(\mathrm{Pb})$ dalam media semakin menurun dengan semakin lamanya waktu kontak antara bakteri dengan media. Setelah waktu inkubasi selama 7 hari didapatkan hasil pengukuran kadar logam timbal $(\mathrm{Pb})$ dari sampel lokasi1.1 konsentrasi logam timbal $(\mathrm{Pb})$ dalam media berkurang dari konsentrasi sebelum degradasi berkisar 0,131 ppm dan sesudah degradasi mengalami penurunan sebesar 0,010 . Hasil dari stasiun 2 atau sampel lokasi 1.2 konsentrasi $\mathrm{Pb}$ sebelum degradasi sebesaar $0,084 \mathrm{ppm}$ dan setelah degradasi mengalami penurunan sebesar $0,006 \mathrm{ppm}$. Pada sampel lokasi 2.1 konsentrasi $\mathrm{Pb}$ sebelum degradasi bekisar 0,174 ppm dan sesudah degradasi mengalami penurunan sebesar 0,007 ppm. Pada sampel lokasi 2.2 konsentrasi $\mathrm{Pb}$ sebelum degradasi berkisar $0,115 \mathrm{ppm}$ dan sesudah degradasi mengalami penurunan sebesar 0,003 . Pada sampel lokasi 3.1 konsentrasi $\mathrm{Pb}$ sebelum degradasi berkisar $0,186 \mathrm{ppm}$ dan sesudah degradasi mengalami penurunan sebesar $0,016 \mathrm{ppm}$. Pada sampel lokasi 3.2 konsentrasi $\mathrm{Pb}$ sebelum degradasi berkisar 0,096 ppm dan sesudah degradasi mengalami penurunan sebesar 0,012 ppm. Pada lokasi 1 konsentrasi $\mathrm{Pb}$ lebih tinggi diduga karena stasiun 1 dekat dengan lokasi pencemar dan juga galangan kapal. Menurut Palar (2004) logam Pb berasal dari tumpahan bahan bakar kapal yaitu mesin yang mengandung TEL (Tetra Ethyl Lead). TEL 
Juvenil, 2(3), 176-185, (2021)

adalah paduan kimia yang terdiri dari ikatan antara karbon $(\mathrm{C})$ dan timbal $(\mathrm{Pb})$.

\section{Rasio Degradasi}

Berdasarkan grafik selisih degradasi dapat dilihat pada Gambar 3. bahwa persentase sebelum dan sesudah degradasi pada sampel pengambilan bulan pertama lokasi pertama dengan kode B1L1 memiliki rasio sebesar $7,63 \%$ dengan penurunan kandungan timbal (pb) sesudah degradasi sebesar 92,3\% sedangkan pada lokasi kedua dengan kode B1L2 memiliki rasio sebesar $7,14 \%$ dengan penurunan kandungan timbal $(\mathrm{pb})$ sesudah degradasi sebesar 92,8\%. Pada sampel pengambilan bulan ke-dua dengan kode B2L1 memiliki rasio antara sebelum dan sesudah degradasi sebesar $4,02 \%$ yang artinya menurun dibandingkan pada pengambilan bulan pertama yaitu dengan persen penurunan $95,5 \%$ sedangkan pada kode B2L2 memiliki rasio degradasi sebesar $2,61 \%$ dengan penurunan kandungan timbal $(\mathrm{pb})$ sesudah degradasi sebesar 97,3\%. Pada sampel pengambilan bulan ke-3 dengan kode B3L1 didapatkan rasio degradasi sebesar $8,60 \%$ dengan persen penurunan sebesar $91,3 \%$, sedangkan pada kode B3L2 didapatkan rasio degradasi sebesar 12,50 dengan persen penurunan kandungan timbal (pb) sesudah degradasi sebesar $87,5 \%$. Jadi perbedaan pada grafik tersebut dipengaruhi oleh beberapa faktor yaitu faktor abiotik dan faktor biotik.

Kemampuan bakteri Pseudomonas aeruginosa dalam menurunkan logam timbal $\mathrm{Pb})$ dapat disebabkan karena bakteri memiliki permukaan sel yang bermuatan negatif karena terbentuk dari berbagai sturuktur anion sedangkan logam berat adalah ion bermuatan positif sehingga dapat terjadi ikatan antara permukaan sel bakteri dan ion logam berat, selain itu mikroorganisme dapat melakukan proses reduksi logam berat sehingga dapat membentuk kompleks ion logam berat yang tidak toksik (Junopia, 2015). Pengikatan logam $\mathrm{Pb}$ oleh bakteri dipisahkan menjadi fase pengikatan dan transport aktif. Fase pengikatan yaitu absorbsi melalui dinding sel atau permukaan eksternal yang tergantung pada metabolisme sel. Kemudian diikuti dengan transport aktif yang tergantung pada metabolisme sel. Logam $\mathrm{Pb}$ dapat terakumulasi pada membran sel (ekstraseluler) dan pada sitoplasma (intraseluler) yang terdapat pada proses metabolisme (Arizzal, 2013).
Bakteri Pseudomonas aeruginosa merupakan bakteri gram negatif yang umumnya mampu tumbuh dalam media tercemar logam berat dan mempunyai kemampuan mengakumulasi logam berat dalam dinding selnya. bakteri yang resisten terhadap logam disebabkan kemampuan untuk mendetoksifikasi pengaruh logam berat dengan adanya protein seperti polifosfat di dalam sel yang mampu mengikat timbal. Sel bakteri sangat berlimpah sisi-sisi yang mengandung muatan negatif yang terletak pada dinding selnya, seperti karboksil (COO-) dan hidroksil (OH-), sehingga akan terjadi interaksi ion logam dengn muatan negatif. Mekanisme biosorpsi logam berat secara alami mempunyai dua mekanisme yang terjadi secara bolak balik yaitu pertamatama akan terjadi penukaran ion logam timbal yang berada disekitar permukaan sel dengan ion monovalen ataupun divalent (misalnya $\mathrm{Na}$ ) dan yang terakhir yaitu pembentukan senyawa kompleks antara ion logam dengan gugus fungsi yang terdapat dalam sel (Khoiroh, 2014).

\section{Kesimpulan \\ KESIMPULAN DAN SARAN}

Kandungan logam timbal $(\mathrm{Pb})$ diperairan Timur Kamal setelah di lakukan Analisa dengan AAS didapatkan hasil kandungan $\mathrm{Pb}$ yang berbedabeda, pada sampel lokasi 1.1 sebesar 0,131 ppm, lokasi 1.2 sebesar 0,084 ppm, lokasi 2.1 sebesar $0,174 \mathrm{ppm}$, lokasi 2.2 sebesar 0,115 ppm, lokasi 3.1 sebesar 0,186 ppm, lokasi 3.2 sebesar 0,096 ppm. Waktu inkubasi optimum untuk menurunkan kadar logam timbal $(\mathrm{Pb})$ yaitu pada hari ke 4 waktu inkubasi, dimana dihari ke 4 bakteri berada pada fase logaritmik yang ditandai dengan nilai OD (Optical density) atau kepadatan bakteri yang pertumbuhannya naik secara cepat. Aktifitas bakteri Pseudomonas aeruginosa dalam menurunkan kandungan logam timbal $(\mathrm{Pb})$ dipelabuhan Timur Kamal selama 7 hari inkubasi yaitu didapat nilai penurunan tertinggi pada sampel lokasi 2.2 dengan penurunan sebesar $97,3 \%$.

\section{Saran}

Perlu adanya penelitian tentang pemakaian bakteri Pseudomonas aeruginosa dalam menurunkan kadar logam berat lainnya seperti logam kadmium $(\mathrm{Cd})$ dan merkuri $(\mathrm{Hg})$ dan Perlu adanya penelitian lebih lanjut mengenai optimalisasi degradasi logam berat timbal $(\mathrm{Pb})$ oleh bakteri dengan memperhatikan berbagai aspek seperti karakteristik limbah $(\mathrm{pH}, \mathrm{BOD}$ dan COD). 
Anggraeni dan Triajie, Uji Kemampuan Bakteri (Pseudomonas aeruginosa)

\section{UCAPAN TERIMAKASIH}

Bismillahirrahmanirrahim, puji syukur sehingga penulis mampu menyelesaikan artikel ini dengan banyak bimbingan, bantuan, dukungan baik dalam bentuk fikiran, doa ataupun finansial dari beberapa pihak. Terima kasih kepada keluarga, dosen dan temanteman yang telah membantu selama penelitian berlangsung. Semoga artikel bermanfaat untuk semua kalangan.

\section{DAFTAR PUSTAKA}

Andriani, M. D., Purnawarman, T., Damayanti, R., Daulay, S., Magister, P., Kesehatan, B., Veteriner, M., Hewan, F. K., Hewan, F. K., Besar, B., Standar, U., Pertanian, K., \& Timur, J. (2016). Identifikasi Listeria monocytogenes pada Susu Kambing di Kabupaten Purworejo Jawa Tengah. 34(7388), 16-23.

Arrizal, S. (2013). Identifikasi Rhizobakteri pada Semanggi (Marsilea crenata Presl.) yang Terpapar Logam Berat Timbal (Pb). LenteraBio: Berkala IImiah Biologi, 2(1), 165-169.

Basha, S. A., \& Rajaganesh, K. (2014). Original Research Article Microbial Bioremediation of Heavy Metals From Textile Industry Dye Effluents using Isolated Bacterial Strains. 3(5), 785794.

Bidayani, E., Rosalina, D., \& Utami, E. (2017). Kandungan logam berat timbal (pb) pada lamun cymodocea serrulata di Daerah Penambangan Timah Kabupaten Bangka Selatan. Maspari Journal: Marine Science Research, 9(2), 169-176.

Caesar, R. Y., Hapsari, I., \& Dhiani, B. A. (2014). Formulasi dan aktivitas antibakteri lotion minyak atsiri buah adas (Foeniculum vulgare mill). Media Farmasi: Jurnal Ilmu Farmasi, 11(1).

Darmono. (1995). Logam Dalam Sistem Biologi Mahluk Hidup. Universitas Indonesia. Press. Jakarta

Darmono. (2008). Lingkungan Hidup dan Pencemaran, Hubungan dengan Toksikologi Senyawa Logam. UI Press. Jakarta.

Dwidjoseputro. (2005). Dasar-Dasar Mikrobiologi.Yogjakarta: Djambatan.

Effendi, H. (2003). Telaah Kualitas Air Bagi Pengelolaan Sumber Daya dan Lingkungan Perairan. Penerbit Kanisius. Yogyakarta.

Keputusan Menteri Lingkungan Hidup No. 51 Tahun 2004 Tentang Baku Mutu Air Laut.
Keputusan Menteri Negara Lingkungan Hidup No.51 Tahun 2004 yang telah diralat pada Nomor 179 Tahun 2004

Khoiroh, Z. (2014). "Bioremediasi Logam Berat Timbal $(\mathrm{Pb})$ dalam Lumpur Lapindo menggunakan Campuran Bakteri (Pseudomonas pseudomallei dan Pseudomonas aeruginosa)". Jurusan Biologi UIN Maulana Malik Ibrahim Malang. H. 1-10.

Landecker dan Moore. (1996). Fundamental of The Fungi. Prentice Hall. New Jersey. 470-476.

Levinson, W., \& Jawetz, E. (2003). Medical Microbiology \& Immunology.

Mohiuddin, K. M., Ogawa, Y. Z. H. M., Zakir, H. M., Otomo, K., \& Shikazono, N. (2011). Heavy metals contamination in water and sediments of an urban river in a developing country. International journal of environmental science \& technology, 8(4), 723-736.

Panuntun, M.S. (2014). "Isolasi dan Identifikasi Bakteri Toleran Terhadap Timbal (Pb) dari Tanah Bekas Cetakan Pengecoran Logam di Desa Jeblokan, Kab.Klaten". Skripsi. Yogyakarta: Fak.Sains dan Teknologi UIN Sunan Kalijaga.

Sulistijowati, R. (2012). Potensi filtrat Lactobacillus acidophilus ATCC 4796 sebagai biopreservatif pada rebusan daging ikan tongkol. Indonesian Journal of Applied Sciences, 2(2), 604-613.

Refdinal, Endah dan Meita. (2014). "Pengaruh $\mathrm{pH}$ dan Temperatur pada Pembentukan Biosurfaktan oleh Bakteri Pseudomonas aeruginosa". Prosiding Seminar Nasional Kimia ISBN. H. 41-48.

Ridwan. (2005). Rumus dan Data dalam Analisis Statistika. Bandung: Alfabeta.

Rizkiana, L. dan Karina. (2017). Analisis Timbal (Pb) Pada Sedimen Dan Air Laut Di Kawasan Pelabuhan Nelayan Gampong Deah Glumpang Kota Banda Aceh Analysis Of Lead (Pb) In Sediment And Seawater At Fishing Port Of Gampong Deah Glumpang, Banda Aceh. Jurnal Ilmiah Mahasiswa Kelautan Dan Perikanan Unsyiah, 2(1), 89-96.

Sanusi, H.S. (2006). Kimia Laut, Proses Fisik Kimia dan Interaksinya dengan Lingkungan. Bogor: Departemen Ilmu dan Teknologi Kelautan, Fakultas Perikanan dan IImu Kelautan. Institut Pertanian Bogor. 188h.

Sudarwin, (2008). Analisis Spasial Pencemaran Logam Berat (Pb Dan Cd) Pada Sedimen Aliran Sungai Dari Tempat Pembuangan Akhir (TPA) 
Sampah Jatibarang Semarang, Tesis,

Program Pasca Sarjana Universitas

Diponegoro, Semarang.

Suharto, B., Susanawati, L. D., \& Wilistien, B. I. (2011). Penurunan kandungan logam $\mathrm{Pb}$ dan $\mathrm{Cr}$ leachate melalui fitoremediasi bambu air (Equisetum hyemale) dan zeolit. Agrointek, 5(2), 148-158.

Suyono, Y., \& Salahudin, F. (2011). Identifikasi dan karakterisasi bakteri Pseudomonas pada tanah yang terindikasi terkontaminasi logam. Jurnal Biopropal Industri, 2(1), 8-13.

Todar, K. (2011). Fermentation of Food By Lactic Acid Bacteria. Todars Online Textbook of Bacteriology.

Umar, M. T. (2001). Kandungan Logam Berat Tembaga $(\mathrm{Cu})$ pada Air, Sedimen dan Kerang Marcia $\mathrm{sp}$ di Teluk Parepare Sulawesi

Wijayati, N., Astutiningsih, C., \& Mulyati, S. (2014). Transformasi?-Pinena dengan Bakteri Pseudomonas aeruginosa ATCC 25923. Biosaintifika: Journal of Biology \& Biology Education, 6(1), 2428.

Yulaipi, S., \& Aunurohim, A. (2013). Bioakumulasi logam berat timbal $(\mathrm{Pb})$ dan hubungannya dengan laju pertumbuhan Ikan mujair (Oreochromis mossambicus). Jurnal Sains dan Seni ITS, 2(2), E166-E170. 